\title{
Use of Standards in Papers Published in Dental Journals
}

\author{
Álvaro DELLA BONA \\ Yuri DAL BELLO \\ Suelen C. SARTORETTO
}

Graduation Program in Dentistry, UPF - University of Passo Fundo, Passo Fundo, RS, Brazil

\begin{abstract}
This study evaluated the use de standards in papers published in Brazilian and international dental journals. Papers published from January 2006 to December 2010 in the following journals were examined: Brazilian Dental Journal (BDJ), Brazilian Oral Research (BOR), Journal of Applied Oral Sciences (JAOS), Journal of Dental Research (JDR) and Dental Materials (DM). In addition to the title and type of study, issue, volume and year of publication, the following information was recorded from each paper: identification of any standard reported in the study; in case of no reported standard, indication if a standard could be used in the study. A total of 3,046 papers were examined, being 937 from DM, 936 from JDR, 489 from JAOS, 348 from BDJ, and 336 from BOR. Considering the papers that could use some standard, DM showed the highest percentage (24.9\%) of reporting standards/paper, followed by JAOS (10.3\%), BOR (10.1\%), BDJ (6.3\%) and JDR (2.4\%), meaning for example that, from 936 papers examined from the JDR, 623 could use some standard but only 15 papers reported them. From all papers examined, $309(10.1 \%)$ reported using some standard. The ISO standards were mostly reported (57.8\%), followed by ASTM standards $(23.7 \%)$ and $74(18.5 \%)$ standards from other international organizations (e.g. ADA and CIE). Despite of the high impact factors of the selected dental journals, their published papers could use standards more often. This study should assist journal editors to encourage authors to consult and refer to available standards to support the scientific papers.
\end{abstract}

Key Words: Standards, dentistry, scientific papers, dental journal.

\section{INTRODUCTION}

International standards give state of the art specifications for products, services and good practice, helping making industry more efficient and effective. Developed through global consensus, they help to break down barriers to international trade (1).

Standards serve a variety of market-perfecting purposes. They provide the basis for comparison of products and establish consistent terminologies through standard definitions, measures, and test procedures. They also promote compatibility of products used in systems, thereby reducing the ranges of variety of products. Not only standards assure desired qualities and performance levels, but they also reduce low quality by providing consumers with an easy check on individual producer quality claims, thereby increasing consumer welfare. As a result, standards can enhance the overall image of industry. The use of standards increases buyer confidence about product quality and in turn may very well increase overall demand for the product, reflecting buyer preference regarding quality. Standards provide for transfer of technologies throughout industry and facilitate introduction of innovation by reducing market and technical risks. They provide the industry with an important marketing tool (2).

The leading current standards are from the International Standards Organization (ISO) and ASTM International, known prior to 2001 as the American Society for Testing and Materials (ASTM). The ASTM was formed in 1898 by chemists and engineers from the Pennsylvania Railroad. At the time of its establishment, the organization was known as the American Section of the International Association for Testing and Materials. Today, the ASTM has more than 30,000 members from 135 Countries $(3,4)$.

The ISO is the world largest standards developing organization. It was born from the union of two

Correspondence: Prof. Dr. Álvaro Della Bona, Programa de Pós-graduação em Odontologia, Faculdade de Odontologia, Universidade de Passo Fundo, Campus I B, São José, BR 285 Km 171, 99001-970 Passo Fundo, RS, Brasil. Tel: +55-54-3316-8395. email: dbona@upf.br 
organizations - the ISA (International Federation of the National Standardizing Associations), established in New York in 1926, and the UNSCC (United Nations Standards Coordinating Committee), established in 1944. Aiming "to facilitate the international coordination and unification of industrial standards", the new organization, ISO, officially began operations on 23 February 1947. Since then, ISO has published more than 19,000 International Standards, ranging from standards for activities such as agriculture and construction, through mechanical engineering, to medical and dental devices, to the newest information technology developments. Today ISO has members from more than 160 countries and more than 150 people work full time for ISO's Central Secretariat in Geneva, Switzerland $(3,4)$.

In addition to ISO and ASTM standards, the American Dental Association (ADA), the accredited dental standards body of the American National Standards Institute (ANSI), also publishes dental standards $(3,4)$.

The ISO dental standards are overseeing by the ISO Technical Committee (TC), namely ISO/TC106, which has published more than 150 dental standards. This is administered by a Secretariat through its standards organization (SCC). TC106 is currently divided into seven Sub-Committees (SC), each with their own Secretariat, that are further divided into convenorled Working Groups (WG), which produce drafts of one or more standard documents. When these drafts reach a definitive status they are released for voting and comments by the national bodies represented in the seven SC of the TC106 $(3,4)$ : SC 1: Filling and restorative materials; SC 2: Prosthodontic materials; SC 3: Terminology; SC 4: Dental instruments; SC 6: Dental equipment; SC 7: Oral care products; SC 8: Dental implants.

With the globalization of knowledge, it is essential to use standards to perform scientific studies, standardizing technical-scientific methodologies and terminology and, therefore, the criteria to allow for comparison between study results. Thus, the objective of the present study was to evaluate the use of standards in papers published in Brazilian and international dental journals during the last 5 years, testing the hypothesis that standards are underused in published dental papers.

\section{MATERIAL AND METHODS}

Two trained examiners evaluated papers published from January 2006 to December 2010 (5 years) in the following journals: Brazilian Dental Journal (Braz Dent J); Brazilian Oral Research (Braz Oral Res); Journal of Applied Oral Sciences (J Appl Oral Sci), Journal of Dental Research (J Dent Res) and Dental Materials Journal for Oral and Craniofacial Biomaterials Sciences (Dent Mater). In addition to the title and the type of study, the issue, the volume and the year of publication, the following information were recorded from each paper: identification of any standard reported in the study; in case of no reported standard, indication if a standard could be used in the study (Table 1).

The ISO and ASTM standards related to the published papers were recorded. The percentage of each examined parameter was calculated.

\section{RESULTS}

A total of 3,046 papers were examined: 937 from the Dent Mater, 936 from the J Dent Res, 489 from the J Appl Oral Sci, 348 from the Braz Dent J, and 336 from the Braz Oral Res (Table 2). Considering the papers that could use some standard, Dent Mater showed the highest percentage $(24.9 \%)$ of papers that actually used them, followed by J Appl Oral Sci (10.3\%), Braz Oral Res (10.1\%), Braz Dent J (6.3\%) and J Dent Res (2.4\%), which means for example that, from 936 papers examined (n) from the J Dent Res, 623 (np) could use some standard, but only $15(\mathrm{nN})$ papers reported the use of at least one standard (Table 2).

From the 3,046 papers examined, 309 (10.1\%) reported the use of some standard. The ISO standards were most frequently reported (57.8\%), followed by 95 ASTM standards (23.7\%) and 74 standards (18.5\%) from other international organizations such as ADA and CIE (International Commission on Illumination). Yet, all of these 74 standards have equivalent standards from ISO or ASTM that could be reported as an alternative.

The most commonly reported standards are summarized in Table 3. Other relevant dental standards are presented in Table 4.

\section{DISCUSSION}

Standards are important tools to scientific research, including dental studies because they describe relevant parameters that substantiate reliable scientific work.

According to the study inclusion criteria, from 
the 2,393 published papers that could use scientific standards, only 309 papers used at least one of them. This implies that $87 \%(n=2,084)$ of the published papers did not use these valuable documents. Despite the relevance of this finding, it seems to be unrelated to the journal's impact factor, considering that J Dent Res, the highest impact factor in the dental literature, presented the worst standard/paper ratio (4.8\%). Dent Mater reported the largest number of standards $(\mathrm{n}=290)$ that were used for 212 published papers. Yet, it accounts for only $24 \%$ $(n=212)$ of the 850 published papers that could use some standard (np) during the evaluated period (Table 2).

From the three Brazilian journals evaluated, the J Appl Oral Sci showed the highest (12.2\%) standard/ paper ratio, followed by the Braz Oral Res (8\%) and the Braz Dent J (6.1\%).

Considering the study design (type of study), the great majority of the papers were original research,

Table 1. Form to collect information from each scientific paper evaluated.

Journal name, issue, volume and year of publication:
Paper title:
Type of study*:
Did the paper use any standard?
( ) Yes Standard number and title?
( ) No Could it use any standard?
If yes, what standard number and title?

*1: original research; 2 : clinical trial; 3 : literature review; and 4: case report. irrespective of the journal evaluated, meaning, from the 3,046 papers, $72.2 \%(\mathrm{n}=2,200)$ were original research, $18.4 \%(\mathrm{n}=560)$ were clinical trials, $7.1 \%(\mathrm{n}=217)$ were literature reviews and $2.3 \%(n=69)$ were case reports. This data is closely related to the use of standards since the papers $(\mathrm{nN})$ that report at least one standard $(\mathrm{n}=309)$, $96.8 \%(\mathrm{n}=299)$ were original research, $2.9 \%(\mathrm{n}=9)$ were literature reviews and only one $(0.3 \%)$ clinical trial (Table 2). Standards were absolutely not reported in case reports, irrespective of the evaluated journal.

The most commonly reported standards refer to ceramics and polymers, such as: the ISO 4049 (Dentistry - Polymer-based restorative materials) reported in 44 papers and the ISO 6872 (Dentistry Ceramic materials) reported in 19 papers (Table 3). This finding may represent the researchers' concern to establish standardization criteria for the work within these biomaterials areas. Yet, the majority of papers that had a chance to report at least one standard $(n p=2,393)$ did not $(2,084)$. Some of the ISO standards that could be reported in these studies are listed in Table 4.

Possible explanations for the low standard/paper ratio are the need of ordering such documents, which may influence researchers and authors to use other published papers as reference for the research methods, and the assumption that standards are not a consensus among authors and reviewers as a standardization parameter.

It is important to mention that the standards used to substantiate papers are sources of information and serve as scientific references for the work. Therefore, they should be properly listed in the references, which was not the case in many of the published papers.

Table 2. Quantitative information on the number of papers examined (n), type of study*, number of papers that could use some standard (np), number of papers that reported the use of at least one standard ( $\mathrm{nN})$, total number of standards used in the examined papers (nNt) and the international organization from where they were published (ISO, ASTM or other).

\begin{tabular}{|c|c|c|c|c|c|c|c|c|c|c|c|}
\hline \multirow{2}{*}{ Journal } & \multirow{2}{*}{$\mathrm{n}$} & \multicolumn{4}{|c|}{ Type of study* } & \multirow{2}{*}{ np } & \multirow{2}{*}{$\mathrm{nN}$} & \multicolumn{4}{|c|}{$\mathrm{nNt}$} \\
\hline & & 1 & 2 & 3 & 4 & & & $\mathrm{nNt}$ & ISO & ASTM & Other \\
\hline Dent Mater & 937 & 876 & 32 & 27 & 2 & 850 & 212 & 290 & 162 & 75 & 55 \\
\hline J Dent Res & 936 & 533 & 266 & 136 & 1 & 623 & 15 & 16 & 9 & 7 & 0 \\
\hline J Appl Oral Sci & 489 & 313 & 125 & 28 & 23 & 370 & 38 & 39 & 26 & 3 & 10 \\
\hline Braz Dent J & 348 & 243 & 57 & 5 & 43 & 303 & 19 & 23 & 18 & 3 & 2 \\
\hline Braz Oral Res & 336 & 235 & 80 & 21 & 0 & 247 & 25 & 33 & 17 & 9 & 7 \\
\hline Total & 3,046 & 2,200 & 560 & 217 & 69 & 2,393 & 309 & 401 & 232 & 95 & 74 \\
\hline
\end{tabular}

*1: original research; 2: clinical trial; 3: literature review; and 4: case report. 
Table 3. The most commonly reported standards presented by the identification number (ID) and describing title, the number of papers that cited the standard (nS), and the number of papers that could cite the standard, including the ones that actually cited it (ncS).

\begin{tabular}{|c|c|c|c|}
\hline Standard ID & Standard title & $\mathrm{nS}$ & $\mathrm{ncS}$ \\
\hline ISO 4049:2009 & Dentistry - Polymer-based restorative materials & 44 & 214 \\
\hline ISO 6872:2008 & Dentistry - Ceramic materials & 19 & 119 \\
\hline ISO 1567 & Dentistry - Denture base polymers & 18 & 18 \\
\hline CIE 15 & Colorimetry & 18 & 18 \\
\hline ISO 10993 & Biological evaluation of medical devices sample preparation and reference materials & 17 & 233 \\
\hline $\begin{array}{l}\text { ISO/TS } \\
11405: 2003\end{array}$ & Dental materials - Testing of adhesion to tooth structure & 15 & 177 \\
\hline ISO 10477:2004 & Dentistry - Polymer-based crown and bridge materials & 10 & 11 \\
\hline ADA 27 & Resin-based filling materials: 1993 & 10 & 10 \\
\hline ISO 9917-1:2007 & Dentistry - Water-based cements - Part 1: Powder/liquid acid-base cements & 9 & 51 \\
\hline ISO/DIS 6876 & Dentistry - Root canal sealing materials & 7 & 37 \\
\hline ISO 9693:1999 & Metal-ceramic dental restorative systems & 7 & 13 \\
\hline $\begin{array}{l}\text { ISO/TR 14569- } \\
1: 2007\end{array}$ & Dental materials - Guidance on testing of wear - Part 1: Wear by tooth brushing & 7 & 13 \\
\hline $\begin{array}{l}\text { ASTM C 1161- } \\
02 \mathrm{c}(2008)\end{array}$ & Standard test method for flexural strength of advanced ceramics at ambient temperature & 7 & 7 \\
\hline ISO 10526 & Standard illuminants for colorimetry & 6 & 9 \\
\hline ASTM C 1322 & Standard practice for fractography characterization of fracture origins in advanced ceramics & 6 & 6 \\
\hline ASTM D 2240 & Standard test method for rubber property & 6 & 6 \\
\hline ADA 57 & Endodontic sealing material: 2000 & 6 & 6 \\
\hline ISO $7491: 2000$ & Dental materials - Determination of color stability & 5 & 8 \\
\hline ISO 10271:2001 & Dental metallic materials - Corrosion test methods & 4 & 15 \\
\hline ISO 4823:2000 & Dentistry - Elastomeric impression materials & 4 & 14 \\
\hline ISO 7405 & Evaluation of biocompatibility devices used in dentistry & 4 & 4 \\
\hline ASTM F 67 & Standard specification for unalloyed titanium, for surgical implant applications & 4 & 4 \\
\hline ASTM C 1499 & $\begin{array}{l}\text { Standard test method for monotonic equibiaxial flexural strength of advanced ceramics at } \\
\text { ambient temperature }\end{array}$ & 4 & 4 \\
\hline ASTM F 394-78 & Standard test method for biaxial flexure strength (modulus of rupture) of ceramic substrates & 4 & 4 \\
\hline ASTM E 399 & Standard test method for linear-elastic plane-strain fracture toughness $\mathrm{K}_{\mathrm{IC}}$ of metallic materials & 4 & 4 \\
\hline ASTM D 790-03 & Standard test methods for flexural properties of unreinforced and reinforced plastic and electrical & 4 & 4 \\
\hline ISO $9917-2: 2010$ & Dentistry - Water-based cements - Part 2: Resin-modified cements & 3 & 15 \\
\hline ISO 15841:2006 & Dentistry - Wires for use in Orthodontics & 3 & 9 \\
\hline $\begin{array}{l}\text { ISO/TS 14569- } \\
2: 2001\end{array}$ & Dental Materials - Guidance on testing of wear - part 2: wear by two and/or three body contact & 3 & 3 \\
\hline ASTM E 647 & Standard test method for measurement of fatigue crack growth rates & 3 & 3 \\
\hline ASTM C 1239-07 & $\begin{array}{l}\text { Standard practice for reporting uniaxial strength data and estimating weibull distribution } \\
\text { parameters for advanced ceramics }\end{array}$ & 3 & 3 \\
\hline ASTM 308-90 & Standard practice for computing the colors of objects by using the CIE system & 3 & 3 \\
\hline
\end{tabular}


Table 4. Other relevant reported ISO standards presented by the identification number (ID) and describing title, the number of papers that cited the standard (nS) and the number of papers that could cite the standard, including the ones that actually cited it (ncS).

\begin{tabular}{|c|c|c|c|}
\hline ISO Standard ID & ISO Standard title & $\mathrm{nS}$ & ncS \\
\hline ISO 10650-1:2004 & Dentistry - power polymerization activators - Part 1: quartz tungsten halogen lamps & 2 & 7 \\
\hline ISO 7489 & Dental glass polyalkenoate cements & 2 & 2 \\
\hline ISO 37:1994 & Rubber, vulcanized or thermoplastic - determination of tensile stress-strain properties & 2 & 2 \\
\hline ISO 178 & Plastics - determination of flexural properties & 2 & 2 \\
\hline ISO 1562 & Dentistry - casting gold alloys & 2 & 2 \\
\hline ISO 1559 & Dental materials - alloys for dental amalgam & 2 & 2 \\
\hline ISO 6344-1 & Coated abrasives - grain size analysis & 2 & 2 \\
\hline ISO 14801 & Dentistry - implants - dynamic fatigue test for endosseous dental implants & 2 & 2 \\
\hline ISO/NP 16506 & Dentistry - polymer-based luting materials containing adhesive components & 1 & 18 \\
\hline ISO $6877: 2006$ & Dentistry - root-canal obturating points & 1 & 11 \\
\hline ISO 3630-1:2008 & Dentistry- Root-canal instruments - Part 1: general requirements and test methods & 1 & 9 \\
\hline ISO $5832-3$ & Implants for surgery - metallic materials & 1 & 9 \\
\hline ISO 1563:1990 & Dental alginate impression material & 1 & 3 \\
\hline ISO 3665 & Photography - intra-oral dental radiographic film & 1 & 2 \\
\hline ISO 1984 & $\begin{array}{l}\text { Test conditions for manually controlled milling machines with table of fixed height - testing of } \\
\text { the accuracy }\end{array}$ & 1 & 2 \\
\hline ISO 15912:2006 & Dentistry - casting investments and refractory die materials & 1 & 1 \\
\hline ISO 14577 & Metallic materials - harness test & 1 & 1 \\
\hline ISO 2039-1 & Plastics - determination of hardness - Part 1: ball indentation method & 1 & 1 \\
\hline ISO $6507-3$ & Metallic materials - vickers hardness test. & 1 & 1 \\
\hline ISO 5799 & Photography - direct-exposing medical and dental radiographic film/process systems & 1 & 1 \\
\hline ISO 16744 & Dentistry - base metal materials for fixed dental restorations & 1 & 1 \\
\hline ISO 13356 & Implants for surgery - ceramic materials based on yttria-stabilized tetragonal zyrconia & 1 & 1 \\
\hline ISO/AWI 17304 & Dentistry - polymerization shrinkage of filling materials & & 51 \\
\hline ISO 11133-1:2009 & $\begin{array}{l}\text { Microbiology of food and animal feeding stuffs - guidelines on preparation and production of } \\
\text { culture media }\end{array}$ & & 40 \\
\hline ISO 24597 & Microbeam analysis - scanning electron microscopy - methods of evaluating image sharpness & & 35 \\
\hline ISO $3630-5$ & Dentistry - root-canal instruments - Part 5: shaping and cleaning instruments & & 24 \\
\hline ISO/ TS 22911:2005 & Dentistry - preclinical evaluation of dental implant systems - animal test methods & & 21 \\
\hline ISO 16408:2004 & Dentistry - oral hygiene products - oral rinses & & 15 \\
\hline ISO 28399:2011 & Dentistry - products for external tooth bleaching & & 15 \\
\hline ISO 3107:2011 & Dentistry - zinc oxide/eugenol cements and zinc oxide/non-eugenol cements & & 14 \\
\hline ISO 11609:2010 & Dentistry - dentifrices - requirements, test methods and marking & & 14 \\
\hline ISO 27020:2010 & Dentistry - brackets and tubes for use in Orthodontics & & 12 \\
\hline ISO / NP 16202-1 & Dentistry - classification and codification of oral anomalies - Part 1: structure of classification & & 12 \\
\hline ISO 20776-2 & Clinical laboratory testing in vitro diagnostic test systems & & 12 \\
\hline ISO 22674:2006 & Dentistry - metallic materials for fixed and removable restorations and appliances & & 11 \\
\hline ISO $6874: 2005$ & Dentistry - polymer-based pit and fissure sealants & & 10 \\
\hline
\end{tabular}


Despite of the high impact factors of the selected Brazilian and international dental journals, the published papers should use standards more often, which confirms the study hypothesis. As the standards substantiate scientific studies and facilitate data comparison among reports, the results of the present systematic review should assist journal editors and reviewers to encourage authors to consult and refer to available standards to support scientific studies and papers.

\section{RESUMO}

Este estudo avaliou o uso de normas científicas em artigos de Odontologia publicados em periódicos brasileiros e internacionais. Trabalhos publicados de janeiro de 2006 a dezembro de 2010 foram examinados nas seguintes revistas: Brazilian Dental Journal (BDJ), Brazilian Oral Research (BOR); Journal of Applied Oral Science (JAOS), Journal of Dental Research (JDR) e Dental Materials (DM). Além do título, tipo de estudo, volume e ano de publicação, as seguintes informações foram registradas a partir de cada artigo: identificação de normas relatadas no estudo; em caso negativo, relatar se alguma norma poderia ser aplicada no estudo. Um total de 3.046 artigos foi examinado como segue: 937 no DM, 936 no JDR, 489 no JAOS, 348 BDJ e 336 no BOR. Considerando os artigos que poderiam usar alguma norma, o DM apresentou o maior percentual (24,9\%) de normas/ artigos relatados, seguido pelo JAOS $(10,3 \%)$, BOR $(10,1 \%)$, BDJ (6,3\%) e JDR (2,4\%), o que significa que de 936 trabalhos analisados do JDR, 623 poderiam ter usado alguma norma, mas apenas 15 relataram o uso. De todos os trabalhos examinados, $309(10,1 \%)$ estudos relataram alguma norma. As normas ISO foram relatadas na maior parte $(57,8 \%)$, seguido pelas normas $\operatorname{ASTM}(23,7 \%)$ e $74(18,5 \%)$ feitas por outras organizações internacionais (por exemplo, ADA e CIE). Apesar do alto fator de impacto dos periódicos selecionados, seus artigos publicados poderiam utilizar as normas com maior frequência. Este estudo deve alertar os editores de periódicos a incentivar os autores a consultar as normas disponíveis para apoiar a metodologia dos trabalhos científicos.

\section{ACKNOWLEDGEMENTS}

This work was partially supported by Capes do Brasil (AUX-PE-PROSUP 2223/2010) and CNPq do Brasil (Grant \#302364/2009-9).

\section{REFERENCES}

1. Jones DW. International Dental Standards. Br Dent J 2007;203:361369.

2. Stanford JW. Guest Editorial: importance of international standardization in dental products. J Dent Res 1987;66:1782.

3. Della Bona A, Wozniak WT, Watts DC. International dental standards - order out of chaos? Dent Mater 2011;27:619-621.

4. Della Bona A, Wozniak WT, Watts DC. The importance of international dental standards. RFO-UPF 2010;15:226-228.

5. Jacobsen P. International standards and the dental practitioner. Dent Update 2008;35:700-702,704.

Received April 13, 2012

Accepted August 15, 2012 